\title{
Four phases of video streaming
}

\section{A case study of medical teaching}

\author{
Mads Ronald Dahl, Aarhus University, CED, Centre for Educational Development \\ Kasper Lauritzen, Aarhus University, CED, Centre for Educational Development \\ Peter Musaeus, Aarhus University, CED, Centre for Educational Development
}

\begin{abstract}
Denne artikel undersøger videostreaming i forskellige undervisningssituationer med varierende grader af studenteraktivering lige fra forelæsninger til team-baseret læring. Artiklen er et casestudie om implementering af video-streaming på Medicin, Aarhus Universitet. Artiklens mål er at udvikle en model af videostreaming i studenter-centreret undervisning. Forskningsspørgsmålet er: Hvad kendetegner faser i video-streaming i forhold til studentercentreret undervisning? Artiklen udvikler en model med fire faser af videostreaming baseret på et empirisk casestudie og teori om læringsdesign. Artiklen argumenterer for at både undervisere, e-moderatorer og studerende spiller en rolle i forhold til at gøre video-streaming til en nyttig undervisningsteknologi. Selvom universitetsundervisere relativt nemt kan udvikle videoer med sin smartphone eller ved hjælp af et digitalt videokamera, er der fordele ved at indlejre teknologien $i$ en social uddannelsessammenhæng $i$ forhold til roller og faser $i$ undervisningsforløb. Undervisningsudviklere skal i samarbejde med undervisere lære at se mulighederne i video-streaming ud fra et undervisningsforløb.
\end{abstract}

\section{Abstract (English)}

This article examines video streaming in teaching situations with varying degrees of student activation ranging from lectures to team-based learning. The article is a case study of the implementation of video streaming at the Department of Medicine, Aarhus University. The aim of the article is to develop a model of video streaming in student-centered teaching. The research question is what characterizes the phases of video streaming in relation to student-centered teaching? The article develops a model with four phases of video streaming based on the case study and the literature on learning design. The article argues that both educators, e-moderators and students play a role in making video streaming a useful teaching technology. There are advantages to embedding the technology in a social educational context in relation to roles and phases of teaching. In collaboration with educators, instructional developers must learn to see the possibilities of video streaming from the perspective of the instructional process. 


\section{Introduction}

Video streaming is a flexible educational technology for teachers and students (Barford and Weston, 1997). The technology enables the student to access a video on a server and view it on demand (Maier and Warren, 2000). It gives the teacher and student the convenience of designing learning objects and using technology strategically before, during, or after lectures (Prince, 2004). Furthermore, since video streaming supports sound, text as well as moving pictures, it can be a lively and perceptually rich experience. Studies show that video streaming can support student learning in mathematics (Kay, 2012), nursing (McKinney and Page, 2009;), the natural sciences (Bridge, Jackson and Robinson, 2009; Gamboa et al., 2001), and medical education (Dong and Goh, 2015; Wang, Mattick, and Dunne, 2010; Shantikumar, 2009; DiLullo et al., 2006; Dev et al., 2000). Thus, there is evidence that video streaming can effectively aid students' review of teaching material and facilitate distance learning. This is relevant if students live far from campus or if the number of students exceed the number of available seats in the lecture hall (Wu and Gao, 2020).

Despite the growing evidence about the efficiency of video streaming for distance learning, it is unclear how teachers should use the technology to support student-centered teaching in varied teaching situations. A significant challenge remains to describe how video streaming best allows students to interact with the video material and use streaming as an opportunity to learn (Laurillard, 1995: 176178). Active student learning can be defined as the person's dynamic process of knowledge construction through means of teacher and peer interaction within a community of learners (Felder and Brent, 2009). Bridge, Jackson and Robinson, 2009). This raises the question whether video streaming can best be used as an active learning activity.

In a systematic review on computer-mediated learning in medical education, Taveira-Gomes et al. (2016) conclude that only few studies have succeeded in putting the student at the center of teaching or giving concrete advice to teachers on how to use video streaming. Learning activities in conjunction with video streaming are needed that lead students to process the material at a deeper level (see McGarr, 2009). Segmenting the video into smaller bits is a technique that helps the students to process information thus taking into account the limited concentration span of humans, including students (Race, 1995). Furthermore, students' deeper processing of material can be facilitated through debates (Kennedy, 2009) and quizzes that stimulate active processing of the material (Karpicke and Grimaldi, 2012). Finally, students can create podcasts to design their own learning material (Lazzari, 2009). All these learning activities might lead to increased student engagement and higher levels of knowledge acquisition (Cheston et al, 2013). However, research is needed to provide systematic approaches to video streaming in situations relating to different phases of university teaching including live lectures and learning activities such as team-based learning (Michaelsen and Sweet, 2011).

The case study we report here is focused on video streaming and learning design in medical education. The objective was to develop a model linking video streaming with different situations of medical teaching ranging from lectures to team-based learning. The research question was what characterizes phases in video streaming in relation to student-centered teaching? We discuss the roles of the lecture, e-moderator and student through four examples. Our proposed model of video streaming is both a technological system that combines streaming software with a student response system, but also a pedagogical environment where lecturer and e-moderator collaborate to redefine the learning situation. 


\section{Background}

\section{Types of video streaming}

Video streaming can be in the form of vodcasts, which are a video on demand broadcast technology. Vodcasts are a mode of mobile learning and it is widely used in healthcare curricula (Boulos et al., 2006; Maar, 2006). With vodcasts, the teacher can regularly publish video excerpts downloaded from the Internet (Rainsbury and McDonnell, 2004). Vodcasts enable the teacher to move material to other devices than computers, such as students' mobile phones (Billings and Kowalski, 2007). Computer systems that support video teaching include systems such as Zoom, Panopto, Skype (for Business), Lifesize, and Adobe Connect. For a description see: https://teachonline.ca or https://www.insidehighered.com. These technologies aim to offer a substitution of live lectures, enabling the same modalities such as voice, body language, slide show and live interaction as lectures.

On the other hand, these technologies presupposes teachers' technological and pedagogical skills in order to make them work. This requires consultancy and continuous support from faculty devlopers with knowledge about how video streaming best can facilitate student learning.

\section{Learning design}

It is fruitful to introduce two models to capture the possibilities and challenges that video technology pose to medical educators. The first model is the SAMR model that deals with integrating technology in the classroom (Puentedura, 2006; 2013). The model consists of four elements:

1. Substitution: Where the integration of technology requires no functional change.

2. Augmentation: Characterized by functional improvement in order to integrate the technology.

3. Modification: Which allows for significant task redesign.

4. Redefinition: Which allows for the creation of new tasks, previously inconceivable.

The second model is the TPACK model (Mishra and Koehler, 2006). It is used for structuring reflections on elements of knowledge required by teachers for successful integration of educational IT. The model consists of three elements:

1. Technological complexity: Technological complexity can be characterized in terms of administration, time consumption, competences needed, scalability, stability and choices. If a production has a high degree of technological complexity, it may require a large amount of technological knowledge and investment.

2. Pedagogical complexity: How comprehensive or socially complex is the educational intervention? An example of an initiative with low pedagogical complexity is not described as part of the curriculum. Rather it may be the teacher's ad hoc initiative to strengthen the students' access to course content. Higher pedagogical complexity may support student centered learning and opportunities for collaboration and high-stake assessment (Anderson and McGreal, 2012).

3. Content knowledge: This is knowledge about the given subject matter. In medical education, it could be basic biosciences such as biochemistry or physiology or clinical subjects such as neurology. The content element in the presented model is the teacher's area of expertise.

Let us give examples of these types of complexities. Low technological complexity could characterize a situation where the medical teacher copy pastes a link to a YouTube video. Low pedagogical complexity 
would generally be characterized in terms of the teacher's routine operation of shorter duration let us say down to only 5 minutes of duration. High technological complexity, on the other hand would be a situation where the teacher needs to meticulously prepare and make ad hoc technical adjustments. High pedagogical complexity would require the teacher to think about substantial changes to the curriculum and means of implementation such as major course redesign.

How does this relate to the learning design models outlines? The SAMR model shows how video streaming should provide for four levels of complexity in teaching. Thus, video streaming should be student-centered to include more than mere substitution where the teacher uploads material. Video streaming should allow students to engage in augmentation, modification of content. The TPACK model is a reminder that complexity is part of university teaching with video streaming technology. We can reduce this technological and pedagogical complexity when students become co-teachers or emoderators who facilitate communication. This might be an example of redefinition of the course where new learning forms become possible. We will investigate phases of a learning design in the following case.

\section{The case study}

From 2018 to 2020, our pedagogical center at Aarhus University offered consultancy and support to medical teachers in their developing live streaming. This was a complex situation with multiple stakeholders and agendas. It led us to design this study as a case study of video streaming in medical teaching because the case study methodology is appropriate to studying a complex phenomenon within a real life context (Stake, 2005; Yin, 1994).

Case studies can use multiple sources of evidence and we gathered data from log files in Blackboard, a learning management system. Furthermore, we collected written data from four teachers' perceptions of their video streaming. We used cluster sampling, which collects every member from the group of students in the semester. Data stemmed from between 180 and 242 medical students from seventh to $12^{\text {th }}$ semester from fall of 2018 to fall 2020.

The study was motivated out of practical concerns. The stakeholders, i.e. dean and administrators of the health faculty, medicine, judged that video streaming could help save time and money. The participating medical students were at the time of the study distributed across different teaching hospitals in Jutland, Denmark. Thus, many students travelled daily with public transportation 63 kilometers from Aarhus university hospital to the regional hospital. However, video streaming could be an efficient educational technology. Furthermore, the stakeholders gleaned to the research literature and judged that the medical faculty could sharpen their visions and usages of video streaming as learning technology.

This led us to develop a video interface as shown in figure 1, which is a screen shot of the tool with an interface in Adobe Connect: 


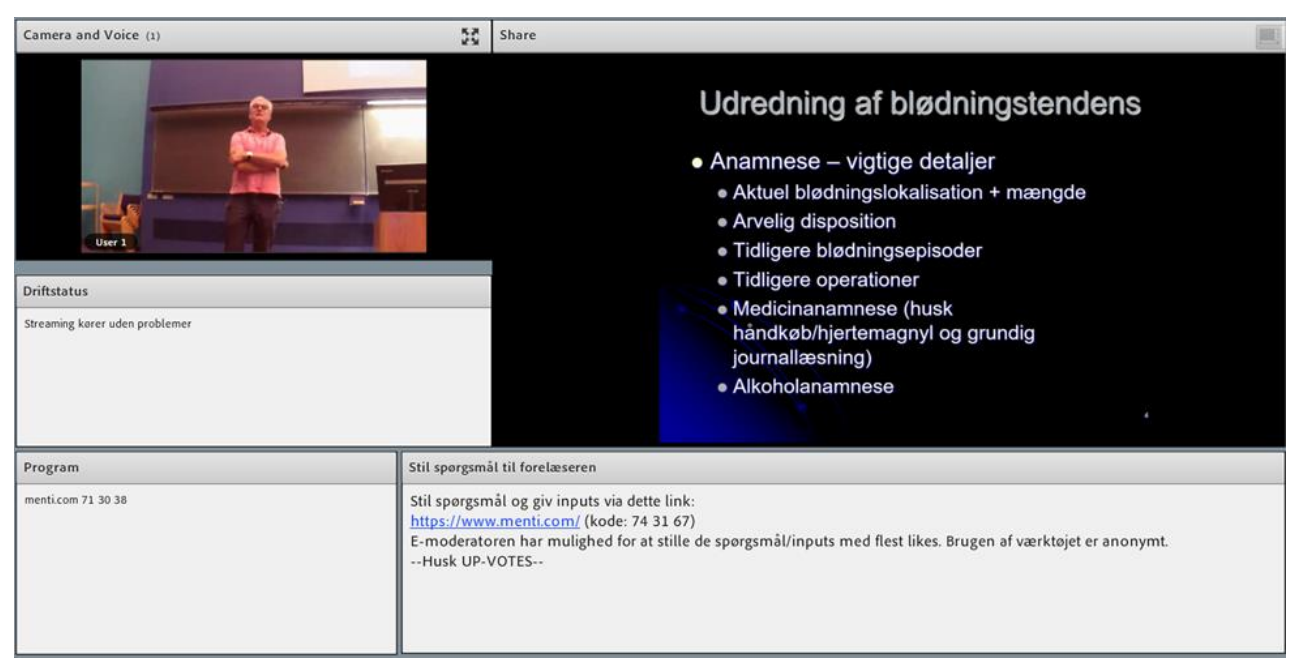

Figure 1. Adobe Connect interface of live streaming on the topic: Anamnesis of bleeding tendency

The interface used live streaming and showed the lecturer, slide show, text fields for operating status and program, and a link to Mentimeter. Figure 1 shows an example of "Anamnesis of bleeding diathesis", i.e. sorting out the patients' tendency to bleed.

\section{Results: Four phases of streaming}

The case consists of three empirical examples. They correspond with three phases of learning design emanating from the SAMR approach (Puentedura, 2006; 2013). We will stipulate a fourth phase that is described with an imaginary or extrapolated example. The model allow us to evaluate a broader range of criteria and possibilities of streaming than we would have had a chance to evaluate empirically.

\section{Phase 1. Substitution: Live video streaming (pilot)}

The first example of video streaming derives from our task of running video streaming as a pilot in the fall of 2018 at Aarhus University. The context was that the Institute of Clinical Medicine faced a number of practical challenges. Participants in the project were the institute leader, 4 teachers, and 180 student.

The institute leader and teachers hoped that live streaming and lecture capturing could produce distance learning. This was motivated by the fact that students received economical compensation (and found it time consuming) when travelling between the clinic and their home. Furthermore, by reducing the number of physically present students, we could use a smaller physical lecture hall.

We divided the class with around 180 students into two groups where students were alternating between lectures and clinical training. This meant that all lectures were held twice each semester. At the same time, many students did not show up for lectures, meaning that if we could initialize and document a flow of students from physical to virtual presence, the institute could cut down on expenses for rent of unnecessarily large auditoriums. However, this created the unforeseen problem that teachers could not store the video equipment when not in use. For this reason, we at our educational center were asked to develop a mobile setup that was small enough to fit into the lecture's suitcase. This was necessary because the video technology could not be installed in a small teaching hall or and where large teaching halls were used for big group teaching.

With the participants, we agreed that our video streaming software should enable teacher-studentinteraction through functions of "raise hand", chat and polls. These activities were not made anonymous. 
To avoid issues of student self-censorship, we used the student response system, Mentimeter. This enabled students to "like" each other's inputs, which created interactivity.

This pilot ran for 4 days with a single course consisting mainly of lectures as shown in table 1 :

Table 1. Data from the phase 1 pilot (lectures from four consecutive days of video streaming).

\begin{tabular}{|l|l|l|l|l|}
\hline $\begin{array}{l}\text { DATA pilot } \\
(\mathrm{N}=218 \text { students) }\end{array}$ & Day 1 & Day 2 & Day 3 & Day 4 \\
\hline Students in auditorium & 150 & 100 & 50 & 30 \\
\hline $\begin{array}{l}\text { Students streaming (on } \\
\text { average) }\end{array}$ & 11.2 & 56.5 & 89.2 & 106 \\
\hline $\begin{array}{l}\text { Highest number of } \\
\text { students streaming }\end{array}$ & 12 & 61 & 101 & 109 \\
\hline $\begin{array}{l}\text { Number of inputs to } \\
\text { teacher on } \\
\text { Mentimeter* }\end{array}$ & 1 & 3 & 23 & 30 \\
\hline $\begin{array}{l}\text { Number of unique } \\
\text { students providing } \\
\text { input }\end{array}$ & 1 & 2 & 9 & 18 \\
\hline
\end{tabular}

The teacher provided information to the students and links to the streaming lectures via Blackboard. The course had 218 students enrolled. Each day the number of students accessing the streaming service increased. The observations suggest that there was an interest in live streaming videos. Thus, students can be moved to virtual learning spaces, and that there was a possibility to arrange inputs through Mentimeter.

The number of inputs to the teacher were only counted if students were addressing the teacher. So for instance, we did not count those instances regarding repetition or third-person statements about the teacher, but not said to the teacher ("I wish he would repeat that part of the lecture"), technical issues ("The sound is too low") or addressing other students (e.g. answering and commenting on each other's questions).

The pilot proved it necessary to have someone who could handle the equipment, secure the quality of the streaming, and handle the inputs from Mentimeter. These tasks would be much too demanding for a lecturer to handle, and especially in a semester where most are clinical lecturers brought in to deliver a single class, it would be too comprehensive to train them in the mobile setup and even just in reading Mentimeter inputs.

The first phase pointed towards a person that could support the lecturer, and thus conserve some aspects of the physical lecture, while bringing it into virtual presence. This person emerged to be the emoderator.

\section{Phase 2. Augmentation: Live streaming to achieve interaction}

While the initial setup was largely a video substitution of the physical lectures, the second phase proved to be an augmentation of the live streaming video using e-moderators. The software and hardware remained technologically relatively unchanged. However, the new model required novel educational 
strategies. It was necessary to hire and train a team of e-moderators who could set up the technological equipment and link the physical lecture with the virtual students. The e-moderators were a group of students who also took part in the course and trained to handle the equipment and task. This also allows the lecturer to focus on their content rather than technology, making the e-moderator a natural link between the lecturer and the video streaming, and by extent a moderator between the virtual students and the lecturer and students physically present.

Besides setting up equipment and monitoring the stream, it is the task of the e-moderator to moderate and present the best-rated inputs in the physical lecture. In that way, the e-moderator is a key component in linking the pedagogical spaces between the lecture hall and the virtual students. The advantage of the e-moderator over technical personnel was that they have the same medical knowledge as their peers writing comments, inputs and questions.

Furthermore, we used the e-moderators to categorize the recorded lectures and to register data on participation. Registration includes documenting how many students are present in the auditorium (approximately), how many students are on the stream (average), and how many inputs on Mentimeter (SRS) are there, registration of technical issues. By collecting these data, we could track, document and compare the quality of streaming (see table 2):

Table 2. Average number of students receiving each lecture.

\begin{tabular}{|c|c|c|c|c|c|c|}
\hline & $\begin{array}{l}\text { 7th sem. } \\
\quad \text { (S19) } \\
\mathrm{N}=190 \\
\mathrm{~L}=30\end{array}$ & $\begin{array}{l}\text { 7th sem. (F19) } \\
\mathrm{N}=218 \\
\mathrm{~L}=33\end{array}$ & $\begin{array}{l}\text { 9th sem. } \\
\begin{aligned} \text { (F19) } \\
\mathrm{N}=215 \\
\mathrm{~L}=30\end{aligned}\end{array}$ & $\begin{array}{l}\text { 9th sem. } \\
\quad \text { (S2O) } \\
\mathrm{N}=197 \\
\mathrm{~L}=30\end{array}$ & $\begin{array}{l}\begin{array}{l}\text { 12th sem. } \\
\quad(S 19) \\
\mathrm{N}=242 \\
\mathrm{~L}=12\end{array}\end{array}$ & $\begin{array}{l}\begin{array}{l}\text { 12th sem. } \\
\quad \text { (F19) } \\
\mathrm{N}=213 \\
\mathrm{~L}=25\end{array}\end{array}$ \\
\hline $\begin{array}{l}\text { Students in } \\
\text { auditorium } \\
\text { (approx.) }\end{array}$ & 34.03 & 24.06 & 69.17 & - & 70.00 & 29.88 \\
\hline $\begin{array}{l}\text { Students } \\
\text { streaming } \\
\text { (avg.) }\end{array}$ & 18.40 & 26.03 & - & - & $75 \cdot 38$ & 68.76 \\
\hline $\begin{array}{c}\text { Total number of } \\
\text { playbacks }\end{array}$ & 150.50 & 123.66 & 74.63 & 166.83 & 80.00 & 178.70 \\
\hline $\begin{array}{l}\text { Unique number } \\
\text { of playbacks }\end{array}$ & 86.03 & 109.40 & 74.63 & 162.10 & 40.58 & 166.43 \\
\hline Total views & 138.47 & 156.19 & 143.80 & 162.10 & 183.62 & 251.76 \\
\hline $\begin{array}{l}\text { Number of } \\
\text { inputs to } \\
\text { teacher on } \\
\text { Mentimeter }\end{array}$ & 1.10 & 5.69 & - & - & 37.54 & $55 \cdot 5^{2}$ \\
\hline $\begin{array}{l}\text { Number of } \\
\text { unique } \\
\text { students } \\
\text { providing } \\
\text { inputs }\end{array}$ & 2.63 & 3.75 & - & - & 18.54 & 20.80 \\
\hline
\end{tabular}

Table 2 depicts the fact that the medical curriculum at the Aarhus University starts two times pr. year. $\mathrm{N}$ indicate the total number of students enrolled at each semester. S19 and F2O is short for spring 
semester 2019 and fall semester 2020. L indicates the total number of lectures live streamed on that semester.

Total number of playbacks (minus the number of streams during the lectures) gives an indication of the number of times the students have accessed the recording afterwards. Lectures that were not recorded are not included in this average. The unique number of playbacks was traced with cookies, so we assume that one student only watches lectures on the same device. Total views is a summation of total students in auditorium, total students streaming and unique playbacks. This number is an estimate of how many students received the lectures.

The streaming at 9 th semester was done as lecture capture without live streaming or interaction. These lectures at 9th semester were held for the last time and video streaming was a way to capture the lectures for future cohorts of students. On request of several students, these were also made available to them to study for exam.

Whereas the first term has also almost equal number of auditorium students and asynchronous streamers (69 and 74 respectively), the second term showing the same videos has a large number of students watching them (166) that is even higher than the students who were offered the physical lectures.

The streaming at 7th semester was done with live streaming, guaranteed recording and enabled live interactions through Mentimeter. These lectures were streamed live at the same time as half of the students were in the clinics, while the other half could either attend the physical sessions or live stream from afar.

Our numbers from both terms indicates a relatively low level of live streamers and physical participants for the lectures, but a high amount of re-plays. At the same time, there was a relatively low level of Mentimeter (SRS) inputs to lecturer - generally around 1-5 inputs posed by 2-4 students. These are often factual questions to the lecturer, rather than inputs to cases and such.

Looking at the fall 2019, the highest number of Mentimeter inputs correlates with a high number of streaming participants, even if the number of students physically present is low.

Finally, the streaming at 12th semester was done with live streaming, optional recording and enabled live interactions through Mentimeter. These lectures were streamed live on Fridays, where students had been in clinic all week, and where they would normally have had to transport themselves from the regional hospital back to Aarhus University Hospital in order to attend the physical lectures. These students could choose to either attend the physical sessions or live stream. However, the lectures were only recorded for asynchronous playback, if the lecturer gave permission on the day of the streaming.

Our data from these streaming sessions show that students only had a moderate level of re-plays, but a high level of live streamers. This was the case for physically present students and interactions. What is most interesting is that the video stream technology used Mentimeter, not only to give inputs to the teacher but also to discuss and collaborate in order to answer doubts posed by the lecturer. This was a qualitative transformation of the input tool for interface program, which to us was designed as a platform solely for lecture inputs, but which instead revealed a lack in the lecture, where students can reflect and collaborate live during a lecture. In this way, the live streaming is augmented with a new layer of student interaction which is not possible in traditional lectures, but which were enabled in the Mentimeter input (SRS). 


\section{Phase 3. Modification: Live streaming using TBL with Zoom}

During the Corona virus outbreak, all university on campus and face-to-face activities, research and teaching was cancelled or had to be conducted online. This demand for digital transformation was extensive and as an example of successful modification, we developed and implemented a live streaming using team based learning (TBL) where students work in groups and solve quizzes in friendly yet competitive atmosphere.

The TBL session used a university installation of Zoom (aarhusuniversity.zoom.us). The session was 2 $\mathrm{h}$ with clinical questions in obstetrics and gynecology for 44 students at 11th semester of the medical curriculum. The professor gave short lectures and facilitated the TBL question tasks using breakout rooms comprising 4-5 students and clarification sessions in the main common room. The feedback from the teacher and students after the session was very positive and the setup worked without IT staff support. The teacher emphasized the realistic clinical environment where problems has to be discussed in teams of random medical professionals and not the same 4-5 colleagues every time. Furthermore, the technology helped isolate each group so that the groups did not inspirer or disturb each other during discussions.

The students asked for a reference to the topics before the TBL session and for questions to be available during breakout room sessions to optimize the workflow. Furthermore the students advocated for integration of the student response system (Mentimeter at AU) to facilitate and visualize voting and answers to questions.

The professor evaluated the transformed TBL session. He asserted that he much preferred the video streaming with TBL above the normal face-to-face classroom session.

\section{Phase 4. Redefinition: Live streaming distributed}

The last example is an imagined example. It is something we designed for, but did not yet put into action. This imagined or future case aimed to decentralize and distribute clinical teaching geographically. Arguably, when the medical student enroll in clinical teaching at a regional hospital, they experience and learn different skills and competencies compared with a large specialized University hospital. If nothing else, they experience a different hospital environment and social setting in a smaller city and hospital. This makes it necessary to design video streaming with e-moderators who can travel to the regional hospitals.

In the future, we therefore hope to have trained a team of student e-moderators. These moderators should be able to operate in both the lecture hall and the clinics. This would enable a directional swap of the communication. Instead of broadcasting from a central lecture hall to the regional clinics, the mobile equipment and the trained e-moderators makes it possible for the regional clinics to stream to the central lecture hall, using their specialist competences, clinical equipment or even current patients to provide content through the affordances of video streaming.

This setup would mean a high complexity of both technical and pedagogical competencies. The satellite network between classrooms and clinics would require the e-moderator's skill in both technical setup and troubleshooting, as well as ability to bridge or negotiate the interaction between lecture hall and clinic). At the same time, these transformations would also mean a redefinition of the various learning spaces. Thus, the lecture hall could be a theoretical overlay on the streamed clinical consultations, whereas the static case material in teaching could be replaced by live sessions. In these live sessions, students in a distant classroom could collaborate with their peers in clinic in order to optimize the examination and treatment. In the other end, even the small regional clinics are enabled to present their expertise and patients to an entire class of students. At the same time, the live streaming and 
collaboration can maintain a stronger connection to the lecture hall and thus the theoretical knowledge that can deepen the clinical experience. Finally, this model would be a way to empower teachers in a regional clinic by aligning the influence on health care education from all the hospitals in westernDenmark.

\section{Concluding discussion}

Having examined four phases of video streaming, we will demonstrate how they represent different positions on the previously mentioned SAMR model with the TPACK-model as depicted in figure 2:

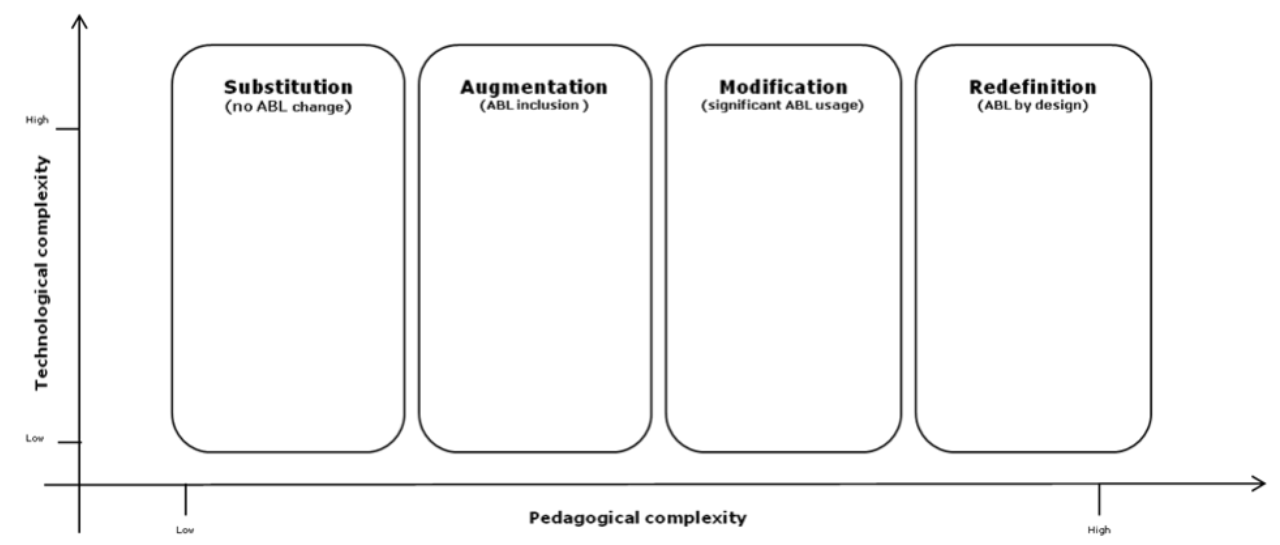

Figure 2. Combined and modified SAMR and TPACK model matrix for video streaming in medical education.

The combined models of SAMR and TPACK represent the four phases of this case study as shown in figure 3 :

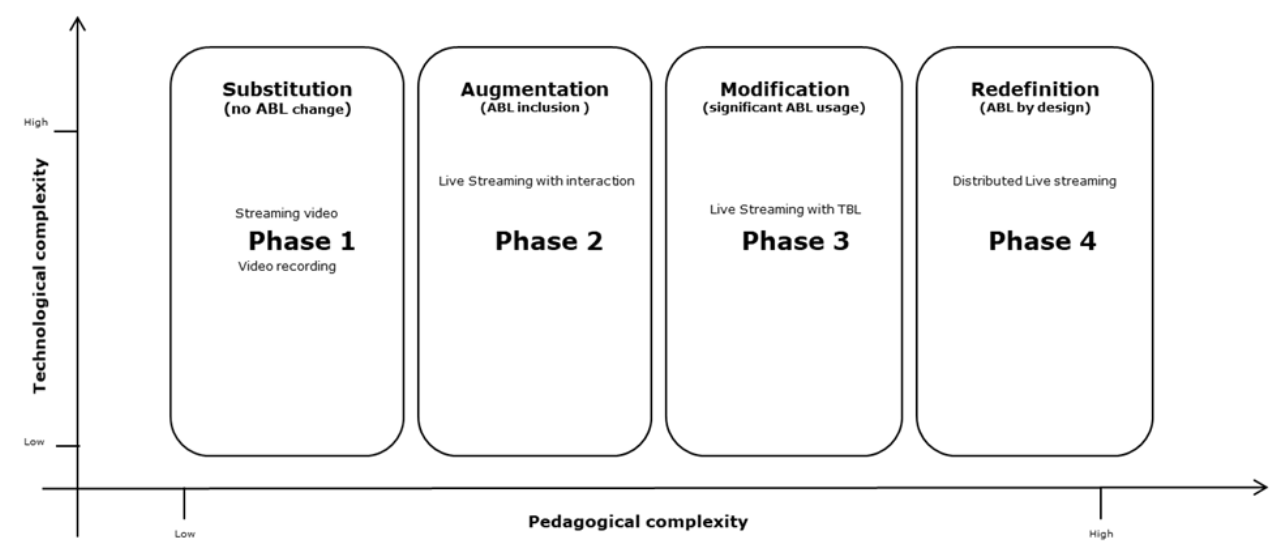

Figure 3. SAMR and TPACK model matrix with the four case examples inserted for video usage in education.

Concerning phase 1: The pilot project without e-moderators and the pure lecture, captures on 9th semester are pedagogical substitutions with a relatively moderate technological complexity. With the introduction of e-moderators, live interaction through Mentimeter, and especially the spontaneous overlay of live, virtual discussion on the 12th semester, the live streaming with e-moderator are a pedagogical augmentation of the normal lectures with a very high level of technological complexity.

Concerning phase 2: Interaction around the course content is traditionally the key teaching and learning element of university education. Hereby providing a model for dialog between a teacher who consider 
the implementation of streaming lectures and teaching and learning experts that can facilitate the transformation.

Concerning phase 3: As the TBL-format enters the live streaming (enabled by e-moderation as well as Zoom's breakout rooms), the live streaming makes a pedagogical modification of moderate technological complexity. Finally, to realize the fully distributed live streaming from de-centralized emoderators in the field would be a format of very high technological complexity and a radical pedagogical redefinition of lecture format, clinical training and the premise of medical education.

Concerning phase 4: The redefinition became relevant to consider when there was a need for the learning space to be expanded. Here the lecture hall becomes an overlay on the streamed clinical consultations. This is both an educational and logistic solution to the problems posed by clinical teaching scattered around different hospitals.

Figure 4 is a summary of our case study where we report the collected written comments from faculty about their perceptions of the potential and current use of video streaming in their teaching:

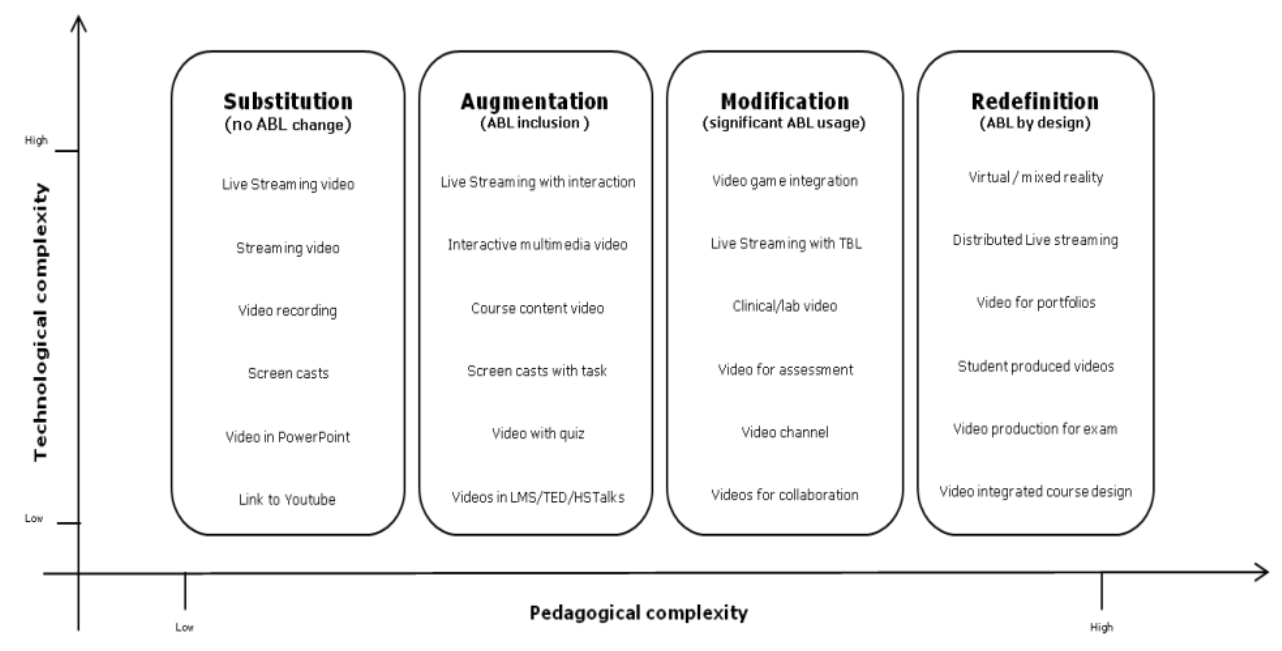

Figure 4. Facilitating discussion around key topics for each phase.

In conclusion, we have shown four phases where video streaming might help in creating active learning that can lead to students construing new knowledge and building attitudes and skills. Video streaming is a technology and not an educational design or philosophy. By combining the SMAR and TPACK models we provided an overview of how and why to use these tools as active learning tools. In conclusion, video streaming in university education might engage students in constructing knowledge. This can happen in collaboration and interactions with fellow students, e-moderators and teachers.

What advantage did our project highlight in terms of video streaming compared with teaching in the clinical environment? Video streaming might help the university teacher to cover more material and better illustrate high-stakes environments e.g., where mistakes are costly to students, compared with traditional lecture methods. Video streaming can be available on demand, i.e. when the student wants to view the material. This allows students to study at their own pace or avoiding massed practice, which is an evidence-based element in active learning (Davis, Chen, Hauff, and Houben, 2018). Video streaming might also be used in real time, i.e. in the form of web casting or multicasting (Van Horn, 2001). Shephard (2003) points out that videos can capture real-life components. However, ideally they should be used in combination with discussion and reflective practices.

Let us conclude with four tips for others working to empower university teachers to use video streaming. First, we should make a careful and respectful assessment of the teachers' skill level. Although it might 
seem as if today most university teachers or students can create videos with their smartphone or a digital camcorder, this does not make for high-level skills. Merely mastering the recording technology hardly determines the final quality of the video stream as educational technology. Thus, be careful before you assume that modern day teachers and students are technologically capable to produce videos. Teachers (and students) lack experience in recording and producing the videos and embedding them in an educational environment suitable to produce active learning. This advice is further motivated by the fact that video technology is constantly developing. It is the question whether the teacher can be expected to master such technology.

Second, we should engage in dialogue with faculty about the opportunity cost of using video streaming. Might there be alternative teaching formats such as case based teaching or problem based learning using text cases that would work better than video streaming? As faculty developers, we need to engage with faculty around dialogues about how video streaming can facilitate learning better than say text-based alternatives. Be ready to identify deeper goals behind the teacher's wish to use video streaming technology. Is the goal to empower students to independently study a given subject (microbiology, gynecology etc.) deeper and at their own pace, preferably without falling behind? Is this a realistic goal, given the complexity of academic subjects? Has the teacher calculated with sufficient time for students to ask questions?

Third, we should be critical about the virtues of video technology compared with other teaching formats. Is video more lively, does it provide more of a real world clinical context, or under what conditions is it more authentic? Is it less of an abstraction than a text-case for instance? Arguably, video seem a more direct, or vicarious experience allowing say the medical student to enact clinical situations. As faculty develops, we need to demonstrate how video streaming is a powerful educational technology that allows for interaction between the teacher and students. One way of showing this to teachers is by working from the model introduced in this case study. We should remember that there are various phases of development in any teaching. We showed four phases in this case, although other phases might have been possible. Our case study depicts increased complexity and means for learners to develop their knowledge, skills, and attitudes as physicians.

Fourth, we should show faculty how video streaming is part of an active and blended learning strategy. Arguably, the great advantage of video streaming is its flexibility as compared to traditional lecturing. In addition, compared to other videos, streaming has the advantage that the student does not have to wait until the video clip is fully downloaded to the students' computer before it begins to play (Zachariah, 2001).

Videos as much as any other representation such as text-based cases are abstractions. Videos can lead to simplification compared with ambulatory teaching, clinical rounds etc. Yet, such simplification can be needed in order to teach principles, prevent students from becoming overburdened, or because the clinical environment does not provide access to all relevant patient cases. Faculty need support to identify elements in videos that act as cues for students to learn to recognize other cues from real world practice.

\section{References}

Anderson, T. \& McGreal, R. (2012). Disruptive pedagogies and technologies in universities. Educational Technological Society, 15: 380-389.

Barford, J. \& Weston, C. (1997). The use of video as a teaching resource in a new university. British Journal of Educational Technology, 28(1): 40-50.

Bennett,P.N. \& Glover, P. (2008). Video streaming: implementation and evaluation in an undergraduate nursing programme, Nurse Education, 28 (2): 253-258.

Billings, D.M. \& Kowalski, K. (2007). Using podcasts for nursing education. The Journal of Continuing Education in Nursing, 38 (2): 56-57. 
Boulos, M.N.K., Maramba, I., \& Wheeler, S. (2006). Wikis, blogs and podcasts: a new generation of Web-based tools for virtual collaborative clinical practice and education. BMC. Medical Education, 6, 41, doi:10.1186/1472-6920-6-41.

Burns, T.M. (2007). The forecast for podcasts: sunny skies but not necessarily with clear visibility. Neurology, 68: E19-E20

Buzzetto-More, N.A. (2014). An examination of undergraduate student's perceptions and predilections of the use of YouTube in the teaching and learning process. Interdiscip Journal of E-Learn Learn Objects, 10: 17-32.

Cheston CC, Flickinger TE, Chisolm MS. (2013). Social media use in medical education: a systematic review. Academic Medicine, 88(6):893-901. [doi: 10.1097/ACM.obo13e31828ffc23] [Medline: 23619071]

Chumley-Jones HS, Dobbie A, Alford CL. (2002). Web-based learning: sound educational methodology or hype? A review of the evaluation literature. Academic Medicine, 77(suppl): 86-93.

Davis, D., Chen, G., Hauff, C., \& Houben, J-G. (2018). Activating learning at scale: A review of innovations in online learning strategies, Computers \& Education, 125: 327-344.

Dev, P., Rindfleisch, T. C., Kush, S. J., and Stringer, J. R. (2000). An analysis of technology usage for streaming digital video in support of a preclinical curriculum. Proc. AMIA Symp, 180-184.

Fill, K. \& Ottewill, R. (2006) Sink or swim: taking advantage of developments in video streaming, Innovations in Education and Teaching International, 43:4, 397-408, DOI: 10.1080/14703290600974008.

Karpicke, J. D., \& Grimaldi, P. J. (2012). Retrieval-based learning: A perspective for enhancing meaningful learning. Educational Psychology Review, 24(3), 401-418.

Kennedy, R. (2009). The power of in-class debates. Active Learning in Higher Education, 10(3), 225-236.

Lau F, Bates J. (2004). A review of e-learning practices for undergraduate medical education. J Med Syst. 28(71): 87. doi:10.1023/B:JOMS.0000021522.30587.ff PMid:15171070

Laurillard D (1995) Multimedia and the changing experience of the learner. British Journal of Educational Technology 26(3): 179-189.

Mishra, P., \& Koehler, M. J. (2006). Technological pedagogical content knowledge: A framework for integrating technology in teachers' knowledge. Teachers College Record, 108 (6), 1017-1054

Mujacic, S., Debevc, M., Kosec, P., Bloice, M. \& Holzinger, A. (2012). Multimedia Tools and Applications. (58): 435-452.

Bonwell, C.C. and Eison, J.A. (1991). Active Learning: Creating Excitement in the Classroom. ASHE-ERIC Higher Education Report 1. Washington, D.C. George Washington University.

DiLullo C, Coughlin P, D'Angelo M, McGuinness M, Bandle J, Slotkin EM, Shainker SA, Wenger C, Berray SJ. (2006). Anatomy in a new curriculum: facilitating the learning of gross anatomy using web access streaming dissection videos. Journal of Visual Commun. Med'., 29(3):99-108. doi: 10.1080/01405110601080738.

Dong, C., \& Goh, P. S. (2015). Twelve tips for the effective use of videos in medical education. Medical teacher, 37(2): 140-145.

Kay, R.H. (2012). Exploring the use of video podcasts in education: A comprehensive review of the literature. Computers in Human Behavior, 28(3), 820-831. https://doi.org/10.1016/i.chb.2012.01.011

Felder, R.M., and Brent, R. (2009). Active Learning: An Introduction, ASQ Higher Education Brief, 2(4).

Gamboa, R., F., Perez, S., J. L., Lara, R., F., Caviedes, C., F., \& Miranda, V., A. I. (2001). A student centered methodology for the development of a physics video based laboratory. Interacting with Computers, 13 (5), 527-548.

Lazzari, M. (2009). Creative use of podcasting in higher education and its effect on competitive agency. Computers \& Education, 52(1), 27-34. https://doi.org/10.1016/i.compedu.2008.06.002

Maag, M. (2006). Podcasting: an emerging technology in nursing education. Student Health Technology Information, 122: 835-836.

McKinney, A., \& Page, K. (2009). Podcasts and video streaming: Useful tools to facilitate learning of pathophysiology in undergraduate nurse education? Nurse Education in Practice, 9(6), 372-376.

McGarr, O. (2009). A review of podcasting in higher education: Its influence on the traditional lecture. Australasian Journal of Educational Technology, 25(3), 309-321. https://doi.org/10.14742/ajet.1136

Michaelsen, L. K., \& Sweet, M. (2011). Team-based learning. New Directions for Teaching and Learning, 128, 41-51.

Mujacic, S., Debevc, M., Kosec, P., Bloice, M., \& Holzinger, A. (2012). Modeling, design, development and evaluation of a hypervideo presentation for digital systems teaching and learning. Multimedia Tools and Applications, 58: 435-452.

Prakash, S.S., Muthuraman, N., Anand. R. (2017). Short-duration podcasts as a supplementary learning tool: perceptions of medical students and impact on assessment performance. BMC Medical Education, 17: 167

Prince, M.J. (2004) Does Active Learning Work? A Review of the Research, Journal of Eng. Education, 93(3): 223-231. 
Puentedura, R.K. (2013). Retrived 17th of June, 2020 from: http://hippasus.com/resources/sweden2010/SAMR_TPCK_IntroToAdvancedPractice.pdf

Puentedura, R.K.. Transformation, Technology, and Education. (2006) Online at: http://hippasus.com/resources/tte/

Race, P. (1995). Making the most of video. SEDA paper, 90: 73-90.

Rainsbury, J.W. \& S.M. McDonnell, S.M. (2006). Podcasts: an educational revolution in the making? Journal of the Royal Society in Medicine, 99: 481-482.

Reed, R. (2001). Streaming technology: An effective tool for e-learning experiences. National Association of Media and Technology Centers' Bulletin, August. 1 - 3 .

Shantikumar, S. (2009). From lecture theatre to portable media: students' perceptions of an enhanced podcast for revision. Medical Teacher, 31: 535-538

Shephard K (2003) Questioning, promoting and evaluating, the use of streaming video to support student learning. British Journal of Educational Technology, 34(3):295-308.

Stake, R. E. (2005). Qualitative Case Studies. In N. K. Denzin \& Y. S. Lincoln (Eds.), The Sage handbook of qualitative research (p. 443-466). Sage Publications Ltd.

Taveira-Gomes, T., Ferreira, P. Taveira-Gomes, I., Severo, M., Ferreira, M.A.. (2016). What are we looking for in computer-based learning interventions in medical education? A systematic review. Journal of Med. Internet Res., 18: e204

Van Horn, R. (2001). Streaming video and rich media. Phi Delta Kappa, 82: 561-562.

Wang, R. Mattick. K. \& Dunne, E. (2010). Medical students' perceptions of video-linked lectures and videostreaming, ALT-J, 18:1, 19-27, DOI: 10.1080/09687761003657622

Yin, R.K. (1994). Case Study Research - Design and Method, 2nd ed., Sage, Newbury Park, CA.

Weiser, C. (2002). Video streaming. Media \& Methods, 38(4), 10-14.

$\mathrm{Wu}, \mathrm{M}$. and Gao, Q. (2020) Using Live Video Streaming in Online Tutoring: Exploring Factors Affecting Social

Interaction, International Journal of Human-Computer Interaction, 36:10, 964-977, DOI: 10.1080/10447318.2019.1706288

Zachariah, K. (2001). A technical view: Streaming Web video. Syllabus, 15(4), 30-31. 


\section{Authors}

\section{Mads Ronald Dahl}

Specialkonsulent

CED, Aarhus Universitet

wiz@au.dk

\section{Kasper Lauritzen}

AC-medarbejder

CED, Aarhus Universitet

kalau@au.dk

\section{Peter Musaeus}

Lektor

CED, Aarhus Universitet

petermus@au.dk
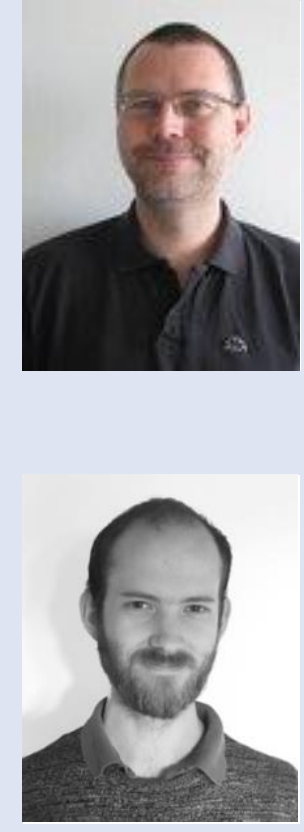